\title{
FAMILY CHARACTERISTICS AND GOVERNANCE OF SMALL AND MEDIUM-SIZED FAMILY FIRMS
}

\section{J. Augusto FELÍ́CIO' ${ }^{1}$, Maria Purificación GALINDO VILLARDÓN²}

\author{
${ }^{1} I S E G$ - School of Economics and Management, University of Lisbon, \\ Rua Miguel Lúpi, n. 20 - Gab. 603, 1200-725 Lisboa, Portugal \\ ${ }^{2}$ Statistics Department, University of Salamanca, \\ C/Espejo s/n Salamanca 37007, Spain \\ E-mails: ${ }^{1}$ jaufeli@iseg.ulisboa.pt (corresponding author); ${ }^{2}$ pgalindo@usal.es
}

Received 29 July 2011; accepted 05 November 2012

\begin{abstract}
The purpose of this paper is to study the influence of family characteristics on the governance of small and medium-sized family firms. The study presents and tests a theoretical model resorting to data on 151 Portuguese SMEs. The study uses nonlinear principal component analysis by alternating least squares, bivariate analysis and cluster analysis. Family characteristics influence governance mechanisms and family firms form clusters based on family characteristics and governance mechanisms. The results reveal that family characteristics are a source of heterogeneity among family firms which corroborates the criticism on family firms' homogeneity assumption. The identification of clusters of firms constitutes a reference for family firms' definition of governance models. The originality of the paper relies on the analysis of specific family characteristics and its importance as a source of family firms' heterogeneity is proven. This study opens new insights on family firms' governance research and may be extended to other family characteristics and overall implications on performance.
\end{abstract}

Keywords: family firms, family characteristics, governance mechanisms, family rituals, family reunions, SMEs.

JEL Classification: G34, M19.

\section{Introduction}

Most businesses worldwide include family firms, especially SMEs. Thus, the success or failure of these firms has significant implications for world economic output, employment and wealth creation (Craig, Moores 2010). Within the context of family firms, relationships are based on certain diffuse and non-contractual elements (Miller, Le Breton-Miller 2006) and family issues and firm issues end up being deeply interconnected. The success of the firm depends more on the efficient management of the overlap between family and business than on the resources of the family, processes or business systems (Chrisman et al. 2003). 
This study differs from previous contributions because it analyzes the effect of rituals and family reunions of small and medium-sized family firms on the governance mechanisms used in these firms. The governance of SMEs, particularly family firms, remains a largely unstudied topic (Bennedsen et al. 2010; Amore et al. 2011; Chrisman et al. 2013). To support this research, we look to the literature on corporate governance (Misangyi, Acharya 2014) and agency theory (Jensen, Meckling 1976).

This paper focuses on the family characteristics and governance mechanisms of family firms. The objectives are to evaluate the influence of the family prestige and branches on the governance arrangements of the firm, and to understand how the relationships of trust established between family members, the family rituals and reunions affect governance mechanisms. The effects of the sector and the age of the firms on those relationships are also studied. To test the hypotheses, we carry out a nonlinear principal component analysis by alternating least squares and a bivariate analysis of the relationships between variables. We also perform a cluster analysis to verify whether family firms can be grouped according to family characteristics and governance mechanisms. The results show that different family characteristics influence governance mechanisms and that family firms form clusters based those relationships evidencing heterogeneity in family firms (Chua et al. 2012).

The next section presents the theoretical background and hypotheses for the study, followed by the conceptual and empirical agenda, analysis and results. The study contains a discussion of the results and conclusions.

\section{Theoretical background and hypotheses}

\section{Family firms}

The expression family firm refers to an organization in which most of the ownership and management duties are concentrated in a single family or branches of that family (Smyrnios et al. 2003; Graves, Thomas 2004). Other authors focus on the family involvement (Deephouse, Jakiewicz 2013).

For the family that owns a SME, the firm serves as a means of achieving several economic and non-economic goals (McGuire et al. 2012). Voordeckers et al. (2007) show that objectives such as maintaining family control, financial independence, family employment and family harmony tend to be more important than maximizing value, income, growth and innovation.

Agency theory states that the interests of shareholders and managers diverge as managers who hold the control of business operations will defend their own financial interests (Singla et al. 2014). An important function of governance mechanisms is to align the interests of managers with the interests of shareholders. Internal governance mechanisms and external family mechanisms operate together and can sometimes replace each other (Fernandez, Arrondo 2005; Bennedsen et al. 2007). There are several key family characteristics, which include the greater or lesser importance of the family brand, the trust relationships established between family members, the rituals adopted, and the formal or informal meetings held. 


\section{Family reunions}

There is a general conviction in the literature that systems of family governance exert a strong influence on the firm (Bennedsen et al. 2010). Family councils often serve as a governance mechanism that maintains trust and unity within the family, cultivates its values, cares for its assets and provides services to the family. Informal meetings, family reunions and councils or assemblies can have an impact on cognitive and affective attributes (Mustakallio et al. 2002). The objective is to instil confidence in the most active members of the firm as well as in shareholders with no job or function. These shareholders participate in decision-making, align their preferences, reduce the risk of conflict and create opportunities for successors to know more about the business (Vileseca 2002; Jaffe, Lane 2004). Consequently, we can formulate the following hypothesis:

H1: The governance mechanisms of family firms are influenced by family reunions.

\section{Trust relationships}

Swift and Hwang (2013) stress the importance of cognitive and emotional trust in organizations. These qualities are especially important within family firms (Mitchell et al. 2003). Mustakallio et al. (2002) indicate that owners have multiple roles in the governance of family firms and that formal and social controls influence the quality of strategic decisions. In family firms, the relationships are based, in general, on a high level of trust, using informal arrangements of governance based on affection instead of utilitarian logic or contractual obligations (Calabrò, Mussolino 2013).

The characteristics of the family firm, combined with the dynamic relationships among the members of the owner family, tend to dominate the boards and encourage conservative attitudes, particularly with regard to business risk (Danes et al. 1999; Hermalin, Weisbach 2003). Accordingly, we can formulate the following hypothesis:

H2: The governance mechanisms of family firms are influenced by trust relationships among family members.

\section{Family brand}

For the first generation, management is usually concentrated in a single person, and thus governance does not receive much attention (Mustakallio et al. 2002; Alesina, Giuliano 2010). The transfer of ownership between generations and the sustainability of family relationships depends on the level of interlacing, and the more intense the interlacing, the more effective the ownership transfer (Dennis, Lane 2004). Family firms tend to retain interests and values and their activities are usually less complex, while personal relationships, both inside and outside the firm, are considered very important (Pugliese 2006). The prestigious family confers credibility to the firm, strengthening commitments by positively influencing the expectations of stakeholders. Consequently, we propose the following hypothesis:

H3: The governance mechanisms of family firms are influenced by the family brand.

\section{Family rituals}

Rituals are an important strength in family firms and can be altered or weakened by generational changes depending on the mutual trust that exists between members (Steier 
2001; Astrachan et al. 2002). Issues of family and work are inextricably linked to cultural beliefs, values and norms (Lobel 1991). Thus, discussions at Christmas parties or at other similar events become an important family characteristic that affects the mechanism of governance in family firms (Johannisson, Huse 2000). We can therefore put forward the following hypothesis:

H4: The governance mechanisms of family firms are influenced by family rituals.

\section{Sector and age}

Family firms focus on various activities because the founders of firms have found opportunities in business areas they generally dominated or knew well. Activity and growth influence the family and family business (Sharma et al. 2003; Pérez-González 2006). The older the firm is, the more generations will have been involved (Sharma et al. 2003). The governance of family firms will be different as the control moves from the founder to the following generations. We can propose the following hypotheses:

H5: The sector influences the relation between the governance mechanisms of family firms and family characteristics.

H6: The age of the firm influences the relation between the governance mechanisms of family firms and the family's characteristics.

\section{Clusters}

Family firms differ due to the governance mechanisms adopted and the characteristics of the family, among other factors. These factors should enable the clustering of family firms into different categories. The analysis of how firms are grouped and the number of clusters allows for a better understanding of the business and the role of governance mechanisms. Consequently, we propose the following hypothesis:

H7: Family firms can be grouped into clusters revealing different relationships between the governance mechanisms and family characteristics.

\section{Conceptual and empirical agenda}

\subsection{The conceptual model}

The model relates to the characteristics of the family identified by variables grouped into family reunions, trust relationships, family brand and family rituals with the governance mechanisms of family firms identified by latent variables labelled as concentration of decision, alignment of interests, involvement in management and openness to outside members (Fig. 1).

\subsection{Variables of the model}

In accordance with the literature, we have selected a total of 20 variables to explain the characteristics of the family. The governance of family firms is characterized by a total of 9 variables. Two control variables, sector and age of the firm, were also considered. Detailed information about the variables and measurement scales is presented in Table 1. 


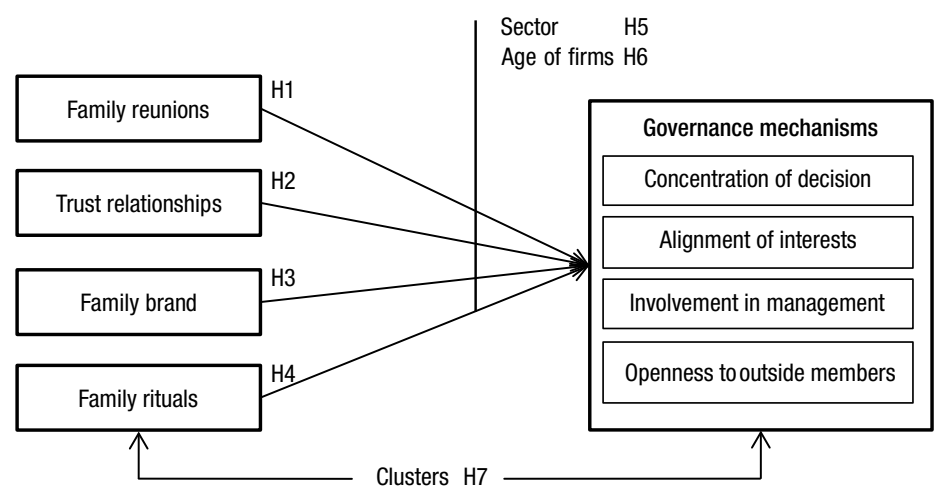

Fig. 1. Conceptual model and hypotheses

Table 1. Detailed information about the variables

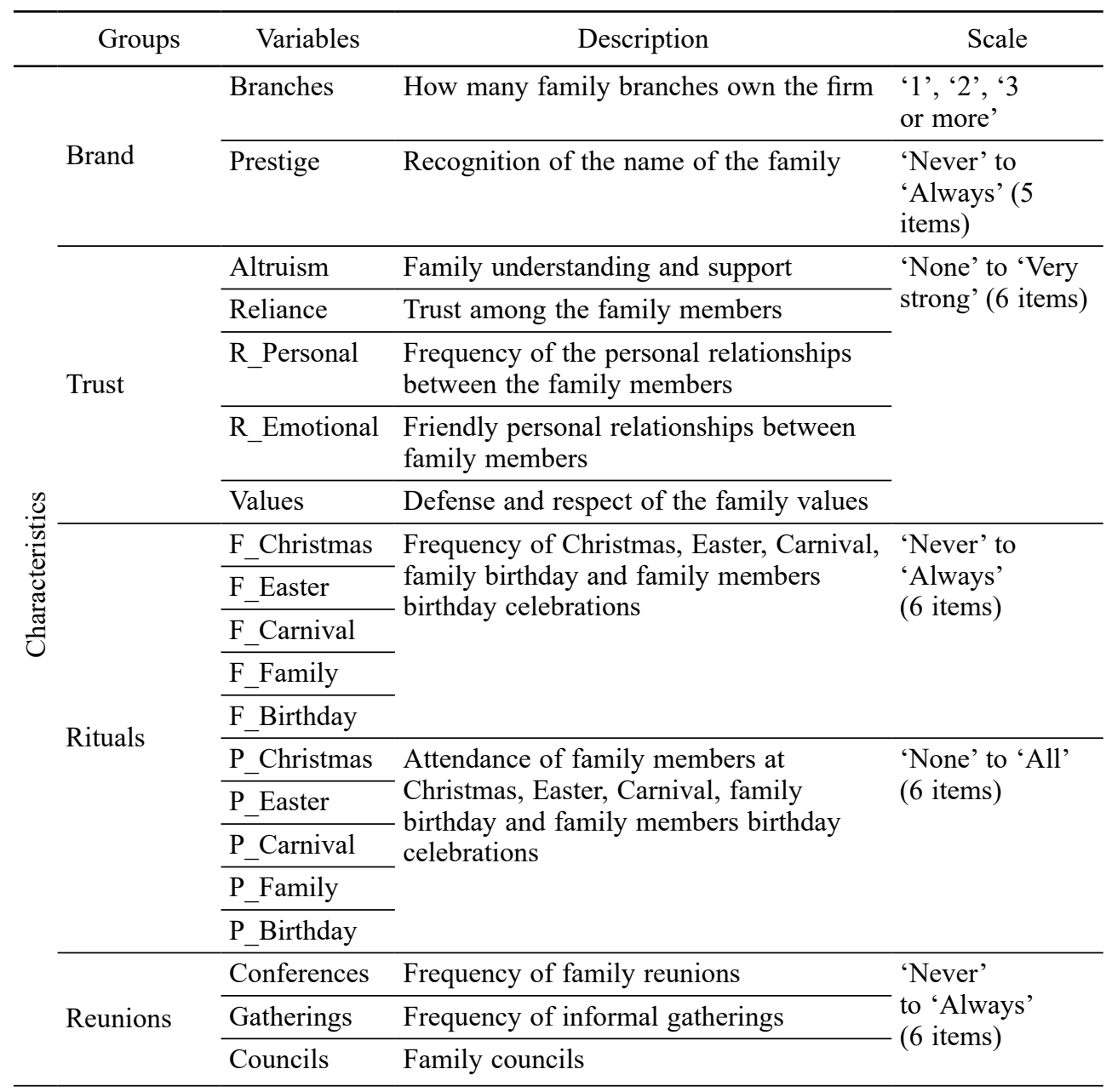


End of Table 1

\begin{tabular}{|c|c|c|c|c|}
\hline & Groups & Variables & Description & Scale \\
\hline \multirow{9}{*}{ 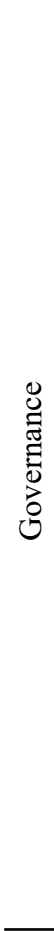 } & \multirow{2}{*}{$\begin{array}{l}\text { Concentra- } \\
\text { tion of } \\
\text { decision }\end{array}$} & Decision & Who has the decision-making power? & $\begin{array}{l}\text { 'The founders' } \\
\text { to 'External } \\
\text { managers' } \\
\text { ( } 7 \text { items) }\end{array}$ \\
\hline & & T_Board & Board size & $\begin{array}{l}\text { Number of } \\
\text { persons }\end{array}$ \\
\hline & & Business & $\begin{array}{l}\text { Discussion of business of firm activity } \\
\text { between owners and managers }\end{array}$ & \multirow{2}{*}{$\begin{array}{l}\text { 'Non-existing', } \\
\text { to 'Very High' } \\
\text { (6 itens) }\end{array}$} \\
\hline & of interests & Connivance & $\begin{array}{l}\text { Degree of understanding or complicity } \\
\text { between the family members and the firm } \\
\text { managers }\end{array}$ & \\
\hline & \multirow{3}{*}{$\begin{array}{l}\text { Involvement } \\
\text { in manage- } \\
\text { ment }\end{array}$} & Involvement & $\begin{array}{l}\text { Percentage of shares held by shareholders } \\
\text { with little or no direct involvement in the } \\
\text { firm }\end{array}$ & $\begin{array}{l}\text { 'Non-existing' } \\
\text { to 'Higher than } \\
50 \% \text { ' }(7 \text { items })\end{array}$ \\
\hline & & Generations & $\begin{array}{l}\text { Percentage of shares held by founders, } \\
\text { sons/daughters, nephews/nieces, } \\
\text { grandsons/granddaughters }\end{array}$ & Percentage \\
\hline & & F_Managers & Family managers & \multirow{2}{*}{$\begin{array}{l}\text { Number } \\
\text { of persons }\end{array}$} \\
\hline & \multirow{2}{*}{$\begin{array}{l}\text { Openness } \\
\text { to outsiders }\end{array}$} & $\begin{array}{l}\text { No } F_{-} \\
\text {Managers }\end{array}$ & Non-family managers & \\
\hline & & $\begin{array}{l}\text { No } F_{-} \\
\text {Shareholders }\end{array}$ & $\begin{array}{l}\text { Percentage of shares owned by non- } \\
\text { family shareholders }\end{array}$ & Percentage \\
\hline
\end{tabular}

\subsection{Empirical agenda}

The research focuses on non-financial firms based in Portugal. The sample consists of 151 small and medium-sized family firms that were active in 2006 and most of the ownership rights were in the hands of a single family or branches of that family. The data was obtained in 2008 through a questionnaire that was mailed to the top managers of firms. We used a random list of 3,000 SMEs.

\section{Methodology}

We explored the primary sources of variation within the two groups of variables, applying a nonlinear principal component analysis by alternating least squares (PRINCALS in SPSS). The process provides an optimum quantification of the firms and categories of variables in the sense that they are as separate as possible in the dimensions studied and within each category firms are reasonably homogeneous. This analysis differs from classical principal component analysis (PCA) because it admits that the relationships may be non-linear and the variables measured in different scales (De Leeuw, Van Rijckevorsel 1980; Gifi 1985). Variable principal normalization was used. Data reduction resulted in factors consisting of variables that showed strong associations. These factors would optimally represent the original information in a reduced number of variables that can be 
seen as a kind of scale construction. The alternating least squares solution might reveal one or more groups of enterprises that dominate the solution. Such a marked deviation from the remaining population would then be regarded as a distinct group, identified by an indicator variable. To check whether the item set represented a single underlying dimension or two underlying dimensions, we used Categorical Principal Components Analysis (CATPCA). The analysis of the relationships between variables was based on the chi-squared test.

Additionally, a k-means cluster analysis was carried out to distinguish the groups of firms according to their characteristics.

\section{Analysis and results}

\subsection{Descriptive analysis}

The main owner of the family firm holds almost $60 \%$ of the capital. Regarding the characteristics of the family, $81 \%$ of managers said that they have 'strong' or 'very strong' respect for family values, $73.3 \%$ said that they feel 'understanding' and/or 'strong' or 'very strong' family support and $83.5 \%$ have a relationship of 'strong' or 'very strong' trust. $74 \%$ of managers said they had 'strong' or 'very strong' friendly relationships with the families. 82.6\% meet 'frequently' or 'very often' at Christmas and $52.4 \%$ meet 'often' or 'very often' at Easter. $63.3 \%$ celebrate family birthdays 'always' or 'very often', and $60 \%$ also meet 'very often' or 'always' to celebrate birthdays of family members.

Regarding the governance of family firms, in $87.5 \%$ of firms, there is only one family branch involved. The decision-making power was controlled by the founders in $49.3 \%$ of firms, by their sons or daughters in $19.2 \%$ and by several members of the families in $24.7 \%$. Only $4.1 \%$ of firms have managers who are not related to the family, and $2.1 \%$ share power between managers and family members. The firm's activities are discussed in $57.7 \%$ of cases between managers and owners; $65.5 \%$ have a 'high' or 'very high' level of common understanding, approximately $60 \%$ meet 'often' or 'very often' for business matters, more than $62 \%$ attend informal meetings and more than $40 \%$ organize family councils to discuss business issues.

\subsection{Exploratory analysis}

In the bivariate analysis of variables, statistically significant relationships were found between family characteristics and corporate governance (Table 2). Decision-making is negatively associated with the level of communication between members and family values (trust relationships), and the frequency of Easter reunions (family rituals). The board size is positively related to informal meetings. With regard to the alignment of interests, there are significant associations in most of the variables that measure the characteristics of the family.

In the case of involvement in the management, a significant positive association was found between the number of generations and existing family branches, between the 


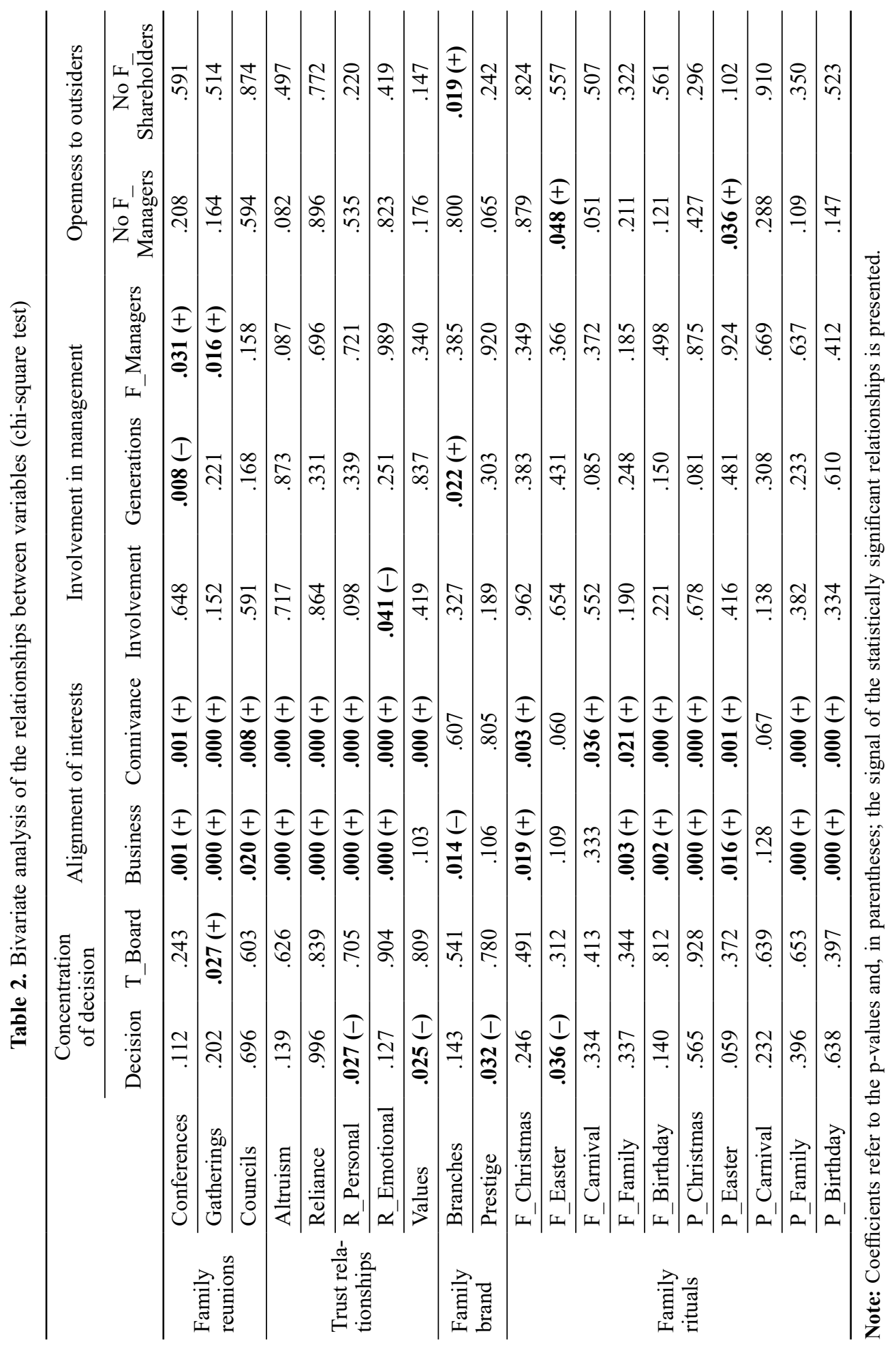


number of family members and family conferences and informal meetings. A negative association was found between the inactive shareholders and friendly personal relationships, and between the number of generations and family conferences. With regard to openness to outside members, there is a significant association between nonfamily shareholders and existing family branches and between external managers and frequency of reunions at Easter.

The principal components analysis solution (PCA) had a total percentage fit (eigenvalues) with no relative loss in the less restricted model. The inertia of the first principal plane (two-dimensional solutions) accounts for $43.1 \%$ of the variability (Table 3 ). The first eigenvalue is significantly higher than the second, meaning that even if the 2 dimensions are considered the first dimension (horizontal) accounts for most of the information $(28.20 \%)$.

To represent the information, we chose 2 dimensions that explain $43.1 \%$ and used a symmetrical normalization procedure that maximizes the distance between the variable categories, while simultaneously measuring the distances between non-similar firms (Fig. 2).

Table 3. Component loadings

\begin{tabular}{lcc}
\hline & \multicolumn{2}{c}{ Dimension } \\
\hline & 1 & 2 \\
\hline Branches & -.193 & -.245 \\
\hline Prestige & .211 & .235 \\
\hline Altruism & .311 & .771 \\
\hline Reliance & .287 & .714 \\
\hline R_Personal & .337 & .655 \\
\hline R_Emotional & .254 & .738 \\
\hline Values & .229 & .726 \\
\hline F_Christmas & .731 & -.338 \\
\hline F_Easter & .764 & -.211 \\
\hline F_Carnival & .626 & .004 \\
\hline F_Birthday & .877 & -.355 \\
\hline F_Family & .846 & -.295 \\
\hline P_Christmas & .750 & -.166 \\
\hline P_Easter & .823 & -.081 \\
\hline P_Carnival & .617 & -.029 \\
\hline P_Birthday & .886 & -.210 \\
\hline
\end{tabular}

\begin{tabular}{lcc}
\hline & \multicolumn{2}{c}{ Dimension } \\
\hline & 1 & 2 \\
\hline P_Family & .869 & -.185 \\
\hline Conferences & .334 & .456 \\
\hline Gatherings & .295 & .379 \\
\hline Councils & .278 & .316 \\
\hline Decision & -.227 & -.181 \\
\hline T_Board & .022 & -.118 \\
\hline Business & .354 & .519 \\
\hline Connivence & .356 & .681 \\
\hline Involvement & -.012 & -.200 \\
\hline Generations & -.150 & .231 \\
\hline F_Managers & .081 & -.035 \\
\hline No F_Managers & .234 & .074 \\
\hline No F_Shareholders & -.071 & -.215 \\
\hline Variance & Eigenvalue & Eigenvalue \\
accounted for: & I & II \\
(\%) & 28.20 & 14.85 \\
\hline Total & & 43.05 \\
\hline & & \\
\hline
\end{tabular}

Variable principal normalization 


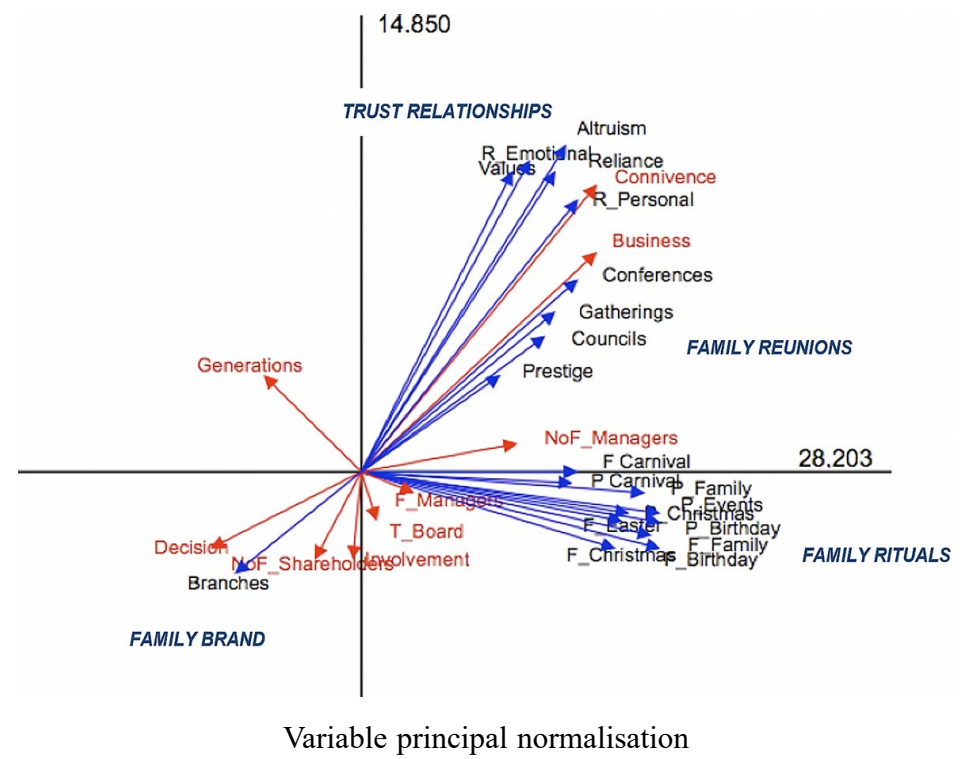

Fig. 2. Representation of variables in the PRINCALS factor plan

Note: Blue vectors refer to family characteristics variables; red vectors refer to the governance mechanisms variables.

The first dimension was defined by 10 variables, all of which are related to family rituals. The second dimension was defined by 8 variables and divided into 3 groups: trust relationships, family reunions (Conferences), and alignment of interests. The variables related to governance mechanisms have no relevance in the definition of the first 2 latent dimensions because they show similar values among all firms in the study; however, it may be important in characterizing firms.

We performed a K-means cluster analysis from principal component analysis coordinates. The cluster analysis yielded 3 distinct subgroups consisting of 18, 52 and 81 firms respectively, and characterized by different combinations of variables (Fig. 3). Firms that represent cluster 1 (green) essentially occupy the second quadrant, corresponding to the set of indicators for the family rituals group that presents a low value, i.e., the frequency with which they meet to participate in events is low ('never', 'rarely', 'sometimes') and the same applies to the Prestige indicator. Decision-making does not remain 'with the founder' in $35 \%$ of these firms, and $17.6 \%$ of managers have nothing to do with the family (openness to outside members). They do not have a defined pattern in the trust relationship or family brand indicators.

The firms that form cluster 2 (yellow) essentially occupy the first quadrant and have high values for the variables: R-Emotional (95\% 'strong' or 'very strong'), Altruism (96\% 'strong' or 'very strong'), Reliance (92\% 'very strong') and R-Personal (75.5\% 'very strong'). The variable Values in the group trust relationships have high values (90\% 'strong' or 'very strong'). The variable Conferences also presents high values in the group family reunions ( $88.3 \%$ 'frequently', 'often' or 'always'), Gatherings $(85.7 \%$ 'often' or 'always') and Councils (71.4\% 'often' or 'always'). All variables in the group 


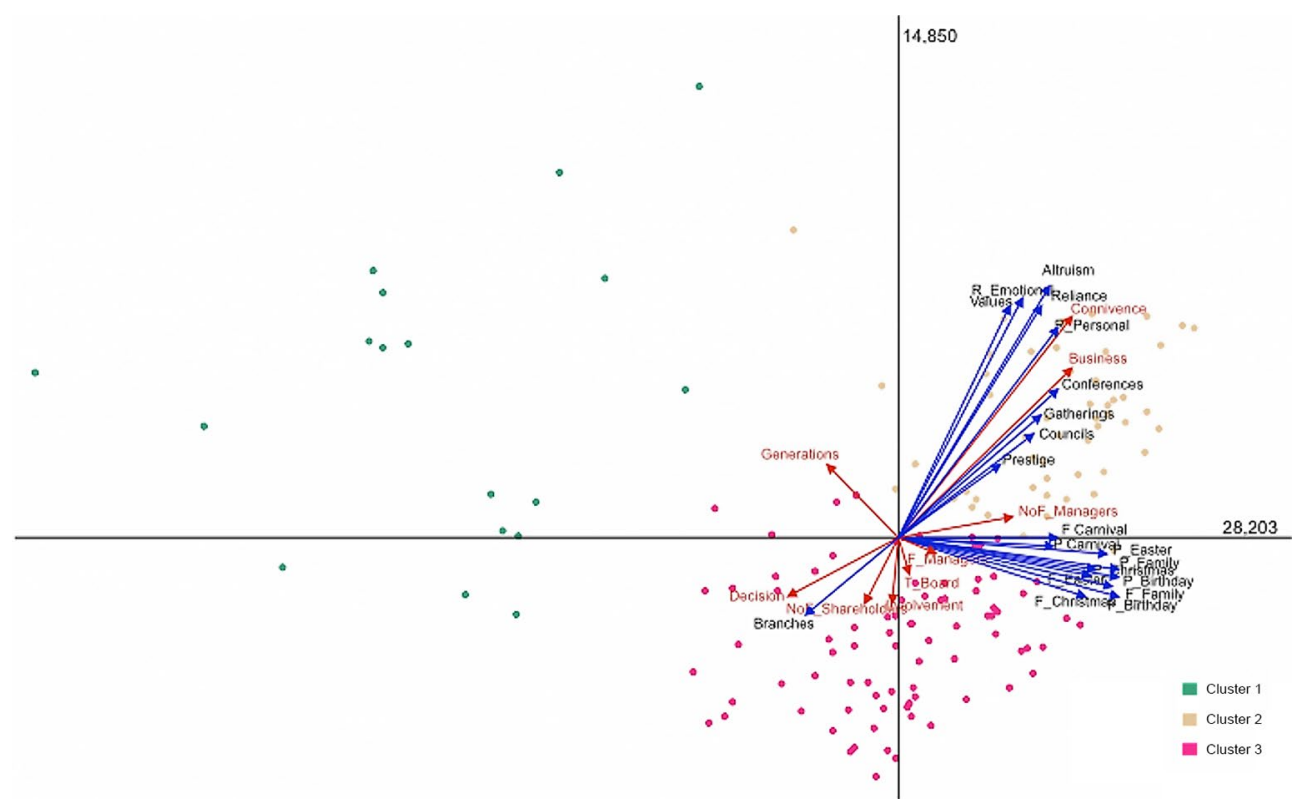

Fig. 3. Representation of variables and firms by cluster

family reunions and the variable Prestige have high values (only 19.2\% 'never' or 'rarely). In cluster 2 , firms have high levels of Connivance ( $94.3 \%$ 'high' or 'very high') and Business ( $82.7 \%$ 'high' or 'very high'). For the other variables, values are low or without a pattern.

The firms that form cluster 3 (pink) are distributed particularly in the third and fourth quadrant. There is no defined pattern of family group variables for this cluster of firms, assuming low values for the variables of the groups trust relationships and family reunions.

Finally, neither the sector nor the age influences the relationship between the characteristics of the family firm and the governance mechanisms.

\section{Discussion}

For larger boards, having family reunions is reflected mainly in the alignment of interests, in the increased discussion within family businesses and in the complicity between the family members on the board of directors, particularly when less generations are involved and there are more family members in management. We notice that formal family meetings are adverse to new generations of shareholders, which, in turn, lend importance to the family brand. Family firms assume the role of family governance to ensure commitments between the firm and the family, share values and provide information to family members (Lank, Ward 2000; Gallo, Kenyon 2004). Usually, however, there is a joint adoption of internal and external mechanisms (Fernandez, Arrondo 2005). The family's characteristics influence the firm's governance mechanisms, namely 
informal gatherings, and family councils or assemblies (Mustakallio et al. 2002). Therefore, $\mathrm{H} 1$ is confirmed.

The relationships of trust between family members are negatively associated with a higher concentration of decision-making powers among the board members and with the existence of inactive members whenever there are friendly and affective relationships. Those relationships of trust are positively correlated with increased business discussion and complicity between family members, and also lead to altruism and family level of confidence, due to the fact that a higher concentration of decisions leads to a lower level of communication and a reduced influence of family values and rituals. Vileseca (2002), Mustakallio et al. (2002), and Jaffe and Lane (2004) confirm that trust relationships and family members influence decision-making and the alignment of interests. However, there are inconsistencies between the objectives of executives and families, resulting in adverse selection and the non-alignment of interests (Morck, Yeng 2003; Gomez-Mejia et al. 2001). Schulze et al. (2003) and Chrisman et al. (2004) consider that many of these problems should be traced to the lack of reciprocal altruism. H2 is thus confirmed.

When family firms involve family branches of different generations they prefer external shareholders. The family branches have no propensity to discuss business with family members. Also, family prestige is adverse to the concentration of decision-making in a family member. Various authors (e.g. Voordeckers et al. 2007) argue that the use of external managers benefits the family firm. However, Sacristán-Navarro and GómezAnsón (2006) consider there to be a preference for turning to internal managers. H3 is therefore confirmed.

Families that establish greater trust among their members and choose to hold family councils have a greater alignment of interests, as reflected in their discussion of business and the complicity among their members, which runs counter to the concentration of decision-making. These relationships are specific for a group of firms. In turn, families practicing their own rituals also opt for external managers to run the family business, which corresponds to another group of firms, just as a larger number of family branches leads to a greater concentration of decision-making power. The adoption of family rituals, including frequency and participation in Christmas celebrations, family parties and birthdays, leads to the alignment of interests reflected in increased discussion of family business, complicity between members and the use of external managers. However, the ritual of the Easter celebration contrasts with the concentration of decision-making and opens up opportunities for non-family managers. Lobel (1991) claims that the issues of family and work are strongly related to cultural beliefs, values and standards adopted by the family. This finding leads Johannisson and Huse (2000) to consider the importance of discussions during Christmas festivities as an important governance mechanism in family businesses. H4 is thus confirmed.

The analysis of the sector of activity of family firms and their age does not provide evidence of its effect on the relationship between family characteristics and mechanisms of governance, and so H5 and H6 cannot be confirmed.

Family firms with multiple generations and family members involved in decision-making which do not adopt the rituals of family make up cluster 1 . In cluster 2 , firms where 
family members set up their relationships based on individual trust, family reunions and recognition of the importance of the prestige of the family without family branches have a strong alignment of interests among family members with corporate interests. In cluster 3 , the various family branches are related to the concentration of decision-making power in the family business with larger boards and show a preference for non-family shareholders. The literature using such an approach in this field of analysis does not abound and $\mathrm{H} 7$ is confirmed.

\section{Conclusions}

This study generally finds that different family characteristics influence governance mechanisms. Family firms tend to group into different clusters based on relationships between family characteristics and governance mechanisms. We conclude that the prestige of the family, relationships of trust and shared values, family rituals adopted and family reunions promote a strong alignment of interests among members of the family and family firms' interest. We also observe that the family brand becomes important insofar as the generational succession of the family gradually moves the firm towards external shareholders and managers.

Another finding shows that family values are important in building relationships of trust between member-owners of the family firm and that active members are more likely to align their interests with the managers through relationships of complicity. In this sense, rituals and family reunions play a strong role in the alignment of interests and complicity, which facilitates the selection of external managers. Furthermore, family reunions tend to be held on an informal basis when the boards are larger and are composed of family member managers.

This paper contributes to the existing literature on governance mechanisms and agency theory in family firms. However, its scope should be extended to firms in different contexts. It presents a relevant innovative contribution to theory and practice by focusing on small and medium-sized family firms and reveals the influence of family rituals on governance mechanisms. The interest and importance of family firms indicates the need to continue researching how they are influenced by other family characteristics and different mechanisms of governance. Future studies should also examine the implications for performance.

\section{References}

Alesina, A.; Giuliano, P. 2010. The power of the family, Journal Economic Growth 15: 93-125. http://dx.doi.org/10.1007/s10887-010-9052-z

Amore, M. D.; Minichilli, A.; Corbetta, G. 2011. How do managerial successions shape corporate financial policies in family firms? Journal of Corporate Finance 17: 1016-1027.

http://dx.doi.org/10.1016/j.jcorpfin.2011.05.002

Astrachan, J. H.; Klein, S. B.; Smyrnios, K. X. 2002. The F-PEC scale of family influence: a proposal for solving the family business definition problem, Family Business Review 15(1): 45-58. http://dx.doi.org/10.1111/j.1741-6248.2002.00045.x 
Bennedsen, M.; Nielsen, K. M.; Pérez-González, F; Wolfenzon, D. 2007. Inside the family firm: the role of families in succession decisions and performance, Quarterly Journal of Economics 122(2): 647-691. http://dx.doi.org/10.1162/qjec.122.2.647

Bennedsen, M.; Perez-Gonzalez, F.; Wolfenzon, D. 2010. The governance of family firms, in K. Baker, R. Anderson (Eds.). Corporate governance. New Jersey, John Wiley \& Sons, 371-389.

Calabrò, A.; Mussolino, D. 2013. How do boards of directors contribute to family SME export intensity? The role of formal and informal governance mechanisms, Journal of Management and Governance 17: 363-403. http://dx.doi.org/10.1007/s10997-011-9180-7

Chrisman, J. J.; Chua, J. H.; Litz, R. A. 2004. Comparing the agency costs of family and nonfamily firms: conceptual issues and exploratory evidence, Entrepreneurship Theory and Practice 28(4): 335-354. http://dx.doi.org/10.1111/j.1540-6520.2004.00049.x

Chrisman, J. J.; Chua, J. H.; Zahra, S. A. 2003. Creating wealth in family firms through managing resources: comments and extensions, Entrepreneurship Theory \& Practice 27(4): 359-365. http://dx.doi.org/10.1111/1540-8520.t01-1-00014

Chrisman, J. J.; Sharma, P.; Steier, L. Pl; Chua, J. H. 2013. The influence of family goal, governance, and resources on firm outcomes, Entrepreneurship Theory \& Practice, 37: 1249-1261. http://dx.doi.org/10.1111/etap.12064

Chua, J. H.; Chrisman, J. J.; Steier, L. P.; Rau, S. B. 2012. Sources of heterogeneity in family firms: an introduction, Entrepreneurship Theory \& Practice 36(6): 1103-1113.

http://dx.doi.org/10.1111/j.1540-6520.2012.00540.x

Craig, J. B.; Moores, K. 2010. Championing family business issues to influence public policy: evidence from Australia, Family Business Review 23(2): 170-180.

http://dx.doi.org/10.1177/0894486510366426

Danes, S. M.; Zuiker, V.; Kean, R.; Arbuthnot, J. 1999. Predictors of family business tensions and goal achievements, Family Business Review 12(3): 41-252.

http://dx.doi.org/10.1111/j.1741-6248.1999.00241.x

De Leeuw, J.; Van Rijckevorsel, J. 1980. Homals and princals - some generalizations of principal components analysis, in E. Diday et al. Eds. Data analysis and informatics. Amsterdam: North-Holland.

Deephouse, D. L.; Jaskiewicz, P. 2013. Do family firms have better reputations than non-family firms? An integration of socioemotional wealth and social identity theories, Journal of Management Studies 50(3): 337-360. http://dx.doi.org/10.1111/joms.12015

Dennis, J.; Lane, S. 2004. Sustaining a family dynasty: key issues facing complex multigenerational business and investment-owning families, Family Business Review 17(1): 5-19.

Fernandez, C.; Arrondo, R. 2005. Alternative internal controls as substitutes to the board of directors, Corporate Governance 13(6): 856-866. http://dx.doi.org/10.1111/j.1467-8683.2005.00476.x

Gallo, M.; Kenyon, D. 2004. The importance of family and business governance, in D. Kenyon, J. L. Ward (Eds.). Family business key issues. Basingstoke: Palgrave MacMillan.

Gifi, A. 1985. Princals. Internal report UG-85-02. Leiden: Department of data theory.

Gomez-Mejia, L.; Nunez-Nickel, M.; Gutierrez, I. 2001. The role of family ties in agency contracts, Academy of Management Journal 44(1): 81-95. http://dx.doi.org/10.2307/3069338

Graves, C.; Thomas, J. 2004. Internationalisation of the family business: a longitudinal perspective, International Journal of Globalisation and Small Business 1(1): 7-27.

http://dx.doi.org/10.1504/IJGSB.2004.005615

Hermalin, B.; Weisbach, M. 2003. Board of directors as an endogenously-determined institution: a survey of the economic literature, FRBYN Economic Policy Review 9(1): 7-26. 
Jaffe, D.; Lane, S. 2004. Sustaining a family dynasty: key issues facing complex multigerational business, and investment owning families, Family Business Review 17(1): 81-98.

http://dx.doi.org/10.1111/j.1741-6248.2004.00006.x

Jensen, M. C.; Meckling, W. 1976. Theory of the firm: managerial behaviour, agency costs and ownership structure, Journal of Financial Economics 3(4): 305-360.

http://dx.doi.org/10.1016/0304-405X(76)90026-X

Johannisson, B.; Huse, M. 2000. Recruiting outside board members in the small family business: an ideological challenge, Entrepreneurship and Regional Development 12: 353-378.

http://dx.doi.org/10.1080/08985620050177958

Lank, A. G.; Ward, J. L. 2000. Governing the business owning family, in C. E. Aronoff, J. H. Astrachan, J. L. Ward (Eds.). (2002). Family business source book. 3rd ed. Georgia: Family Enterprise Publishers, 462-481.

Lobel, S. A. 1991. Allocation of investment in work and family roles: alternative theories and implications for research, Academy of Management Review 16: 507-521.

McGuire, J.; Dow, S.; Ibrahim, B. 2012. All in the family? Social performance and corporate governance in the family firm, Journal of Business Research 65: 1643-1650.

http://dx.doi.org/10.1016/j.jbusres.2011.10.024

Miller, D.; Le Breton-Miller, I. 2006. Family governance and firm performance: agency, stewardship and capabilities, Family Business Review 19(1): 73-87.

http://dx.doi.org/10.1111/j.1741-6248.2006.00063.x

Misangyi, V. F.; Acharya, A. G. 2014. Substitutes or complements? A configurational examination of corporate governance mechanisms, Academy of Management Journal 57(6), 1681-1705. http://dx.doi.org/10.5465/amj.2012.0728

Mitchell, R.; Morse, E.; Sharma, P. 2003. The transacting cognitions of non-family employees in the family business setting, Journal of Business Venturing 18: 533-551.

http://dx.doi.org/10.1016/S0883-9026(03)00059-4

Morck, R.; Yeung, B. 2003. Agency problems in large family business groups, Entrepreneurship: Theory \& Practice 27(4): 367-382.

Mustakallio, M.; Autio, E.; Zahra, S. 2002. Relational and contractual governance in family firms: effect on strategic decision making, Family Business Review 15(3): 205-222.

http://dx.doi.org/10.1111/j.1741-6248.2002.00205.x

Pérez-González, F. 2006. Inherited control and firm performance, American Economic Review 96(5): 1559-1588. http://dx.doi.org/10.1257/aer.96.5.1559

Pugliese, A. 2006. Determinants of boards strategic involvement in small firms: an empirical analysis of Norwegian companies, in M. Huse, et al. (Eds.). Boards and governance: best paper proceedings from the EURAM boards and governance track in Oslo 2006: 37-60.

Sacristán-Navarro, M.; Gómez-Ansón, S. 2006. Family ownership, corporate governance and firm value: evidence from the Spanish market, in P. Z. Poutziouris, K. X. Smyrnios, S. Klein (Eds.). Family business research handbook. Cheltenham, Glos. UK: Edward Elgar Publishing, 593-613.

Schulze, W. S.; Lubatkin, M. H.; Dino, R. N. 2003. Toward a theory of agency and altruism in family firms, Journal of Business Venturing 18(4): 473-490.

http://dx.doi.org/10.1016/S0883-9026(03)00054-5

Sharma, P.; Chrisman, J. J.; Chua, J. H. 2003. Succession planning as planned behaviour - some empirical results, Family Business Review 16(1): 1-15.

http://dx.doi.org/10.1111/j.1741-6248.2003.00001.x 
Singla, C.; Veliyath, R.; George, R. 2014. Family firms and internationalization-governance relationships: evidence of secondary agency issues, Strategic Management Journal 35: 606-616. http://dx.doi.org/10.1002/smj.2111

Smyrnios, K. X.; Romano, C. A.; Tanewski, G. A.; Karofsky, P. I.; Millen, R.; Yilmaz, M. R. 2003. Work-family conflict: a study of American and Australian family businesses, Family Business Review 16(1): 35-51. http://dx.doi.org/10.1111/j.1741-6248.2003.00035.x

Steier, L. 2001. Family firms, plural forms of governance, and the evolving role of trust, Family Business Review 14(4): 353-367. http://dx.doi.org/10.1111/j.1741-6248.2001.00353.x

Swift, P. E.; Hwang, A. 2013. The impact of affective and cognitive trust on knowledge sharing and organizational learning, The Learning Organization 20(1): 20-37.

http://dx.doi.org/10.1108/09696471311288500

Vileseca, A. 2002. The shareholder role in the family business: conflict of interests and objectives between non employed shareholders and top management team, Family Business Review 15(4): 299-320. http://dx.doi.org/10.1111/j.1741-6248.2002.00299.x

Voordeckers, W.; Van Gils, A.; Van den Heuvel, J. 2007. Board composition in small and medium sized family firms, Journal of Small Business Management 45(1): 137-156.

http://dx.doi.org/10.1111/j.1540-627X.2007.00204.x

J. Augusto FELÍCIO is professor, President of the Centre for Management Studies and Research Fellow at the Centre for Advanced Research in Management at the School of Economics and Management (ISEG), University of Lisbon. His research interests cover the areas of entrepreneurship, family firms, human capital and social capital, corporate governance and strategy.

Maria Purificación GALINDO VILLARDÓN is professor and director at the Statistics Department of the University of Salamanca. Her main research interest is in multivariate data analysis, particularly the application of biplot and correspondence analysis. 